\title{
Transgenic Mouse Models of Alzheimer's Disease
}

\author{
Gregory A. Elder ${ }^{1,3,4}$, Miguel A. Gama Sosa ${ }^{2,3}$, and Rita De Gasperi ${ }^{2,3}$ \\ ${ }_{1}^{1}$ Neurology Service, James J. Peters Department of Veterans Affairs Medical Center, Bronx, NY \\ ${ }^{2}$ Research and Development Service, James J. Peters Department of Veterans Affairs Medical \\ Center, Bronx, NY \\ 3 Department of Psychiatry, Mount Sinai School of Medicine, New York, NY \\ ${ }^{4}$ Department of Neurology, Mount Sinai School of Medicine, New York, NY
}

\section{Abstract}

\begin{abstract}
Alzheimer's disease is the most common cause of senile dementia in the United States and Europe. At present, there is no effective treatment. Given the disease's prevalence and poor prognosis, the development of animal models has been a high research priority. Transgenic modeling has been pursued on the basis of the amyloid hypothesis and has taken advantage of mutations in the amyloid precursor protein and the presenilins that cause familial forms of Alzheimer's disease. Modeling has been most aggressively pursued in mice, for which the techniques of genetic modification are well developed. Transgenic mouse models now exist that mimic a range of Alzheimer's disease-related pathologies. Although none of the models fully replicates the human disease, the models have contributed significant insights into the pathophysiology of $\beta$-amyloid toxicity, particularly with respect to the effects of different $\beta$ amyloid species and the possible pathogenic role of $\beta$-amyloid oligomers. They have also been widely used in the preclinical testing of potential therapeutic modalities and have played a pivotal role in the development of immunotherapies for Alzheimer's disease that are currently in clinical trials. These models will, without a doubt, continue to play central roles in preclinical testing and be used as tools for developing insights into the biological basis of Alzheimer's disease.
\end{abstract}

\section{Keywords}

Alzheimer's disease; amyloid precursor protein; animal model; presenilins; transgenic mice

\begin{abstract}
Alzheimer's disease (AD), the most common cause of senile dementia in Europe and the United States, accounts for an estimated $50 \%$ to $80 \%$ of all cases. Clinically, AD is characterized by progressive cognitive impairment, usually beginning as memory loss but eventually progressing to involve multiple cognitive and behavioral domains. Pathologically, the disease is recognized by the presence of senile plaques, neurofibrillary tangles (NFTs), and neuronal loss. At present, there is no effective treatment. Given the prevalence and poor prognosis of the disease, the development of animal models has been a high research priority.
\end{abstract}

\footnotetext{
Address Correspondence to: Gregory A. Elder, Neurology Service, James J. Peters Department of Veterans Affairs Medical Center, Bronx, NY, gregory.elder@mssm.edu.

DISCLOSURES

Potential conflict of interest: Nothing to report.
} 


\section{ALZHEIMER'S DISEASE AS A CANDIDATE DISEASE FOR MODELING IN TRANSGENIC ORGANISMS}

Transgenic technology exists for many organisms, including mice, rats, fish, flies, and worms. Modeling in invertebrates such as Drosophila and Caenorhabditis elegans offers advantages in terms of the high degree of experimental control and the relatively short life span of the organisms. They, however, suffer the disadvantage of being far removed phylogenetically from mammals. Although efforts to model AD in these systems continue, they have had less impact than models in mammalian systems and are not discussed further. The interested reader is, however, referred to 2 recent reviews of transgenic modeling of $\mathrm{AD}$ in Drosophila and C. elegans. ${ }^{1}, 2$ Among vertebrates, mice are by far the species most used. Transgenic modeling in mice is relatively inexpensive. Mice also have a relatively short life span, and the techniques for performing genetic modifications in them are well developed. Transgenic technology exists for rats but is not as widely available as that for mice, although some transgenic $\mathrm{AD}$ rat lines have recently been described. ${ }^{3}{ }^{3} 6$

Regardless of the species chosen, transgenic technologies introduce genetic modifications. Therefore, successful modeling requires the disease to be associated with a genetic mutation or at least for a hypothesis to exist regarding the likely pathophysiology of the disorder that can be modeled by a genetic modification. To be useful as an animal model, the transgenic organism must also be able to exhibit the essential pathological, physiological, or behavioral features of the human disease.

AD may in many ways be regarded as the ideal disease for modeling in transgenic animals. First, it has a well-recognized pathology consisting of senile plaques and NFTs. The major constituents of these lesions are well defined, being the $\beta$-amyloid (A $\beta$ ) peptide in the case of plaques and hyperphosphorylated forms of tau in NFTs. AD also has other wellrecognized pathological features, including neuronal and synaptic loss, dystrophic neurites, reactive astrocytes, and activated microglia. There is, in addition, a well-defined behavioral phenotype that can be modeled in the mouse.

In $\mathrm{AD}$, the $39-$ to $42-$ amino acid $\mathrm{A} \beta$ peptide deposits in senile plaques. ${ }^{7}$ The $\mathrm{A} \beta$ peptide itself is derived from the processing of a larger precursor protein known as the amyloid precursor protein (APP). Many in vitro and in vivo studies have demonstrated that, in particular, the longer $\mathrm{A} \beta 42$ species can be neurotoxic. The amyloid cascade hypothesis postulates that shunting of amyloid precursor protein (APP) processing toward $\mathrm{A} \beta$ production sets off a chain of pathological events, ${ }^{7}$ a process that can be modeled in transgenic animals. In addition, although most cases of $\mathrm{AD}$ occur sporadically, autosomal dominant forms of the disease exist that mimic the sporadic disease clinically and pathologically. Mutations in 3 genes including APP have been identified as causing familial Alzheimer's disease (FAD) ${ }^{8}$ Indeed, the amyloid hypothesis was greatly bolstered by the finding that mutations in APP can cause FAD. These familial cases thus provide a genetic lesion that has been used to advantage in AD modeling in transgenic animals.

\section{METHODS FOR GENERATING TRANSGENIC ORGANISMS}

Transgenic organisms are generated by 1 of 2 general strategies. In the first, a genetic modification is introduced on top of the existing genetic makeup of the organism. In the second, the homologous gene of interest is modified selectively in its normal chromosomal position; this process is called gene targeting. These strategies have been developed to different degrees in different organisms. 
In mice, both approaches are highly developed. In the first approach, a 1-cell embryo at the pronuclear stage is injected with a transgene. The transgene contains the coding region, often in the form of a complementary DNA of the protein of interest, coupled to a promoter that drives expression. The promoter is typically not the promoter of the native gene but rather a heterologous promoter chosen because of its strength or pattern of expression. However, transgenes may also consist of segments of genomic DNA that contain the gene of interest, often in the form of bacterial artificial chromosomes or P1 artificial chromosomes, in which case the transgene is driven by its native promoter and enhancers. The injected transgene integrates randomly, typically in multiple copies at a single site. Because no corresponding allele exists on the homologous chromosome opposite the integration site, these mice are usually called hemizygous. Because the heterologous promoters chosen are typically strong, the transgenic protein is often expressed at levels higher than would be present physiologically. In addition, because the mouse typically contains its own endogenous version of the gene, the transgene is generally expressed on top of the background expression of the mouse's endogenous gene, and this leads to further overexpression.

With gene targeting, instead of a foreign transgene being introduced, an endogenous gene in the mouse is modified. Initially, the modification is made in specialized cells termed embryonic stem (ES) cells. ES cell lines are derived from early-stage mouse embryos and can be maintained indefinitely in an undifferentiated state in vitro yet retain the capacity, when injected back into an early-stage mouse embryo, to mix with the endogenous cells of the embryo and contribute to all tissues of the developing mouse, including the germ line. The gene of interest is modified in ES cells by the introduction of a targeting vector that consists of a modified version of the endogenous gene. In ES cells, the targeting vector recombines with the homologous endogenous gene and thereby introduces the genetic modification. Gene targeted ES cells are then injected into wild type blastocyst-stage mouse embryos with the chimeric mice that result being mixtures of the modified ES cells and wild type blastocyst cells. The successful integration of the ES cells into the germ line permits the genetic modification to be propagated as part of the mouse genome, and this creates stable transgenic lines.

Gene targeting technology has been most commonly used to produce null mutations or gene knockouts. However, it can also be used to selectively modify endogenous mouse genes down to the level of introducing single nucleotide changes, producing what are known as knock-in mice. In contrast to pronuclear injection, in which multiple copies of a transgene are inserted randomly, in gene targeting, the normal mouse gene is modified in its normal chromosomal position. Thus, although in pronuclear injection a transgene is typically overexpressed and often misexpressed spatially and temporally because of its coupling to a heterologous promoter, a gene-targeted allele is expressed at normal levels and in a normal temporal and spatial expression pattern.

\section{TRANSGENIC MODELING BASED ON OVEREXPRESSION OF THE AMYLOID PRECURSOR PROTEIN}

Given the availability of methods for introducing genetic modifications, modeling in transgenic mice has been vigorously pursued on the basis of the amyloid hypothesis.9-11 Initially, before the discovery of FAD mutations, attempts were made to overexpress wildtype APP in transgenic mice by pronuclear injection. Although a variety of promoters were tried, none of these efforts produced anything that resembled an amyloid plaque or any other recognizable AD-type pathology. 
After the discovery of FAD mutations in APP, a number of groups turned their attention to making AD models based on the overexpression of transgenes containing FAD mutations. Games et al. 12 reported the first successful application of this approach using a platelet derived growth factor- $\beta$ (PDGF) promoter to drive a human APP transgene that contained an FAD associated mutation (V717F). The PDGF promoter was chosen because, despite its name, it was known to be highly expressed in the central nervous system and to drive strong expression of exogenous transgenes in neurons. In the line that was generated (termed PDAPP because of the PDGF promoter plus APP), 40 copies of the transgene integrated, and this resulted in an approximately 18-fold elevation of APP RNA and an approximately 10 -fold elevation of human APP protein in comparison with endogenous mouse APP levels. Proportionate increases in human $\mathrm{A} \beta$ were found.

PDAPP mice exhibited age-dependent amyloid deposition in the brain along with thioflavin$\mathrm{S}-$ positive plaques, including compact plaques with dense cores that were highly reminiscent of those seen in human AD. Dystrophic neurites, reactive astrocytes, and activated microglia were all found near plaques. The process was age-related, in that plaque deposition was minimal at 6 months of age but readily apparent by 9 months, increasing dramatically by 12 to 15 months. ${ }^{13}$ PDAPP mice were subsequently shown to develop agerelated learning defects ${ }^{14}$ and synapse loss. ${ }^{15}$

Independently, Hsiao et al., ${ }^{16}$ taking a relatively similar approach, overexpressed a human APP transgene containing the Swedish FAD mutation (K670N/M671L). Expression was driven by a hamster prion [prion protein (PrP)] promoter that drives expression widely in the nervous system. These mice, termed Tg2576 mice, expressed human APP at levels more than 5-fold above the levels of the endogenous mouse APP, and A $\beta 40$ and A $\beta 42$ levels increased with age. Like PDAPP mice, Tg2576 mice exhibited age-dependent amyloid deposition, which resulted in thioflavin-S-positive plaques similar to those found in AD, along with gliosis and dystrophic neurites. Plaque amyloid was first clearly seen by 11 to 13 months, eventually becoming widespread in cortical and limbic structures. Water maze learning, a test of spatial memory in mice, was normal in 3-month-old animals but impaired in 9- to 10-month-old mice. The Tg2576 mouse line has been made widely available and has been the most widely studied transgenic AD model.

Subsequently, many other transgenic lines were developed with approaches similar to those used to develop PDAPP and Tg2576 mice ${ }^{9}{ }^{11}$ typically relying on strong promoters to drive expression of APP transgenes containing single or multiple FAD mutations. Common features of the models have been the production of elevated levels of $\mathrm{A} \beta$, amyloid plaques, dystrophic neurites, and gliosis. Behavioral deficits have been common. ${ }^{10}$ Many additional neuropathological, electrophysiological, and neurochemical changes that model aspects of $\mathrm{AD}$ in humans have also been observed. ${ }^{10}$

Yet, although the models exhibit many similarities, they differ in certain aspects, one being the temporal profile of plaque deposition. For example, TgCRND8 mice, which express multiple APP mutations, exhibit parenchymal amyloid deposition as early as 3 months of age. ${ }^{17}$ APP23 mice, in which a Thy-1 promoter is used to drive expression of the Swedish mutation, are notable for their prominent vascular amyloid deposition and resultant congophilic angiopathy. ${ }^{18}$ PDAPP and Tg2576 mice also differ in some aspects; for example, in $\mathrm{Tg} 2576$ mice, both $\mathrm{A} \beta 40$ and $\mathrm{A} \beta 42$ are increased more or less proportionately, whereas in PDAPP mice, A $\beta 42$ is disproportionately elevated. ${ }^{16}{ }^{19} \mathrm{In}$ Tg2576 mice, most amyloid deposits in dense cored plaques, and $\mathrm{Tg} 2576$ mice have relatively few of the diffuse deposits found in PDAPP mice. Tg2576 mice are also known for their giant plaques ${ }^{20}$ and exhibit more vascular amyloid deposition, ${ }^{19}$ which is largely absent in PDAPP mice. 
Variations between lines likely reflect the different promoters used, the effects of the distinct mutations or combinations of mutations, and the genetic backgrounds on which the transgenes have been maintained. PDAPP mice, for example, have been mostly studied on a highly mixed C57BL6/DBA/Swiss-Webster background. By contrast, Tg2576 mice are typically studied on a hybrid C57BL6/SJL background. Indeed, the $\mathrm{Tg} 2576$ transgene has been difficult to move off this background and leads to early death on an FVB/N background. $^{21}$

\section{TRANSGENIC MODELING WITH PRESENILIN MUTATIONS}

Presenilin 1 (PS1) was found as part of a search for an early-onset FAD gene associated with a locus on chromosome $14 .{ }^{8}$ Mutations in PS1 are the most commonly recognized causes of early-onset FAD, and to date, more than 160 mutations in PS1 linked to FAD have been discovered (see http://www.molgen.ua.ac.be/ADMutations). Mutations in a related gene on chromosome 1, now called presenilin 2(PS2), were soon linked to FAD as well. ${ }^{8}$

APP is a transmembrane protein with the $\mathrm{C}$-terminus of the $\mathrm{A} \beta$ region located within the intramembranous domain. ${ }^{22} \mathrm{~A} \beta$ is generated by the sequential cleavage of APP by a set of secretases. $\beta$-secretase cleaves APP at the $\mathrm{N}$-terminus of the $\mathrm{A} \beta$ peptide, generating a $\mathrm{C}$ terminal fragment that becomes the substrate for $\gamma$-secretase, which generates the $\mathrm{A} \beta \mathrm{C}$ terminus. By contrast, a third secretase, known as $a$-secretase, cleaves APP within the A $\beta$ domain, precluding the generation of $\mathrm{A} \beta$. Presenilins are best known for their role as part of the multiprotein complex known as $\gamma$-secretase, which executes the intramembranous cleavage of many transmembrane proteins, including APP. ${ }^{23}$ Presenilin FAD mutations cause APP processing to be shunted toward the longer, more amyloidogenic A $\beta 42$ species $^{23}$; an observation that can be been seen as supportive of the amyloid hypothesis.

PS1 FAD mutant transgenic lines have been generated with many of the same promoters used to create APP mice, including PDGF ${ }^{24}$ and PrP. ${ }^{25},{ }^{26}$ A few PS2 FAD mutant lines also exist. In addition, several gene-targeted lines exist in which PS1 FAD mutations have been targeted to the endogenous mouse PS1. ${ }^{27}{ }^{29}$ Presenilin FAD mutant mice consistently show elevations of $\mathrm{A} \beta 42$ with little if any effect on $\mathrm{A} \beta 40$. However, singly transgenic PS1 or PS2 mice do not develop plaques, although when crossed with plaque-forming APP lines, the presenilin FAD mutations cause earlier and more extensive plaque formation. ${ }^{30}$ Why singly transgenic PS1 and PS2 mice fail to develop plaque pathology is not entirely clear, but may be related to the generally lower levels of $\mathrm{A} \beta 42$ found in single presenilin transgenics versus APP-overexpressing lines as well as the lack of elevation of $\mathrm{A} \beta 40$ in presenilin transgenics. It may also be related to the differing aggregation properties of mouse $\mathrm{A} \beta$ versus human $\mathrm{A} \beta$. 31

Although PS1/APP bigenic mice have been frequently studied, the parental presenilin lines have been less studied, likely because of their lack of a robust AD-like pathology. However, PS1 and PS2 FAD mutant lines show exaggerated hippocampal damage after kainateinduced excitotoxicity, ${ }^{27},{ }^{32}, 33$ and PS1 FAD mutants render animals more sensitive to trimethyltin-induced hippocampal damage. ${ }^{34}$ Excessive neuronal loss in the entorhinal cortex also occurs in mice harboring the deltaE9 PS1 FAD mutation after lesioning of the perforant path. ${ }^{35}$ Increased protein oxidation and lipid peroxidation have also been reported in PS1 FAD mutant brain. ${ }^{36},{ }^{37}$ Several studies have documented impaired hippocampal neurogenesis in adult PS1 FAD mutant mice, ${ }^{38}{ }^{42}$ and recently, an age-dependent impairment of spine morphology and synaptic plasticity in hippocampal cornu ammonis 1 neurons of a PS1 transgenic mouse model has been described. ${ }^{43}$ Age-related neurodegenerative changes with neuronal loss have been reported in one PS1 FAD mutant line ${ }^{44}$ and age-related NFT-like inclusions have been described in a PS1 knock-in line. ${ }^{45}$ 
Recently, a microvascular pathology that is highly reminiscent of the microvascular pathology found in $\mathrm{AD}$ has also been described. ${ }^{46}$ Thus, presenilin FAD mutant mice exhibit a phenotype. What is less clear is why they fail to exhibit the full range of ADrelated pathologies, given the potency of the mutations in humans.

\section{RELEVANCE AS MODELS OF ALZHEIMER'S DISEASE}

Transgenic mouse models now exist that mimic a range of AD-related pathologies. Table 1 contains a summary of some of the more widely studied mouse models. As discussed later, these models have suggested new insights into the pathophysiology as well as novel therapeutic approaches. The models, however, raise a number of issues as well. First, it is clear that the success of transgenic mouse models has depended on the overexpression of APP transgenes containing FAD-associated mutations at levels that are not physiological. Indeed, many proteins, if overexpressed at sufficient levels, will become toxic at some point. It might be argued, therefore, that it is hardly surprising that overexpressing a naturally amyloidogenic protein would lead to amyloid deposits. However, interestingly, even though a number of APP wild transgenic lines have been created, only 1 transgenic mouse line overexpressing wild-type APP has been described that develops plaques. ${ }^{47}$ Thus, in general, overexpression of wild-type APP in the mouse does not induce plaque pathology, and the pathology that is seen seems to require the presence of an FAD mutation.

It is interesting in this context to compare the overexpression models to APP knock-in mice harboring the Swedish mutation introduced into the mouse APP gene. ${ }^{48}$ These mice should represent the most authentic model of human FAD in the mouse, and because the 3 amino acid differences between mouse and human APPs in the $\mathrm{A} \beta$ region were modified, these mice also produce human $\mathrm{A} \beta$. Yet, despite increased $\mathrm{A} \beta$ production, no amyloid plaques or neuropathology develops in these mice.

Overexpression of APP in Down's syndrome is associated with AD pathology in humans. ${ }^{49}$ Recently, families have been identified in which a duplication of the APP gene leads to FAD, presumably because of overexpression of wild-type APP. ${ }^{50},{ }^{51}$ Thus, there is a precedent for APP overexpression leading to AD in humans. Yet, there is no evidence for APP overexpression in either sporadic AD or in FAD associated with APP or presenilin mutations.

It is also not clear that the temporal appearance of plaque pathology and cognitive deficits in the mouse models mirrors that of the human disease. Indeed, many of the mouse models exhibit behavioral deficits before significant plaque pathology. ${ }^{10}$ By contrast, substantial plaque pathology is probably present for some period of time before cognitive symptoms first appear in human AD. ${ }^{52}$ Interpretations of behavioral studies in the mouse are also complicated by the fact that it is difficult to know how precisely the behavioral tests used in mice model the cognitive deficits in humans.

Transgenic mouse models have also been troubled by the difficulty of producing the full spectrum of AD pathologies, including neuronal loss. For example, neither PDAPP nor Tg2576 mice, despite having extensive amyloid deposition, exhibit neuronal loss. 53,54 APP23 mice show only modest losses of cornu ammonis 1 pyramidal cells (about 15\%), 55 losses that are far less than those observed in AD. More substantial neuronal loss has been reported in mice expressing multiple PS1 and APP mutations. ${ }^{56}{ }^{58}$ For example, mice harboring 2 APP and 1 PS1 FAD mutation show a $35 \%$ loss of hippocampal neurons. ${ }^{57}$ In another study, 2 APP mutations (APP-Swedish/APP-London) expressed from transgenes were crossed onto a mouse line that had 2 presenilin FAD mutations (M233T/L235P) knocked into the mouse PS1 gene. Besides amyloid pathology, extensive neuronal loss $(>50 \%)$ occurred in the hippocampus. ${ }^{56}$ Finally, 3 APP and 2 PS1 FAD mutations recently 
were combined to create a $5 \mathrm{X}$ FAD mutant mouse, and grossly apparent neuronal loss was observed. ${ }^{58}$ Thus, neuronal loss can be induced in the mouse but only, it would seem, by the combination of multiple mutations that individually are sufficient to cause disease in humans.

Another problem with the models has been the general difficulty of inducing the characteristic cytoskeletal pathology of AD in transgenic mice. ${ }^{59}$ NFTs are recognized by their propensity to stain with histological dyes, such as thioflavin-S and Congo red, and by ultrastructurally containing paired helical filaments. NFTs contain hyperphosphorylated forms of tau as well as conformationally altered tau epitopes that can be recognized by specific antibodies. In PDAPP mice, phosphorylated tau epitopes do accumulate within dystrophic neurites in animals 14 months of age or older, ${ }^{60}$ and within these neurites, 12 - to 15 -nm filaments can be seen, but there are no paired helical filaments and no lesions with the histological staining properties of NFTs. Other models have been similar in their lack of any NFT-like pathology. Various suggestions have been advanced for the difficulty of inducing NFT-like lesions in the mouse, including differences between human and mouse tau and the shorter life span of the mouse. However, the reasons remain unexplained.

Recently, mice that exhibit NFT-like lesions and plaques have been produced by combining FAD mutations with mutant forms of tau found in a distinct form of dementia known as frontotemporal dementia and parkinsonism linked to chromosome 17 (FTDP-17). ${ }^{61}$ FTDP-17 is part of the spectrum of frontotemporal dementias (FTDs) that include Pick's disease, progressive supranuclear palsy, and corticobasal degeneration. ${ }^{61}$ In these disorders, hyperphosphorylated forms of tau accumulate in NFTs in the absence of neuritic plaques. FTD cases present clinically with often prominent behavioral disturbances or isolated language defects and relatively preserved memory initially. Like AD, most FTD occurs sporadically. However, in some families with FTDP, the disease is caused by mutations in the tau gene on chromosome 17 (FTDP-17). Mutations, including exonic point mutations, which alter the protein coding sequence, and intronic mutations, which affect splicing or the level of tau expression, have all been identified.

Lewis et al. ${ }^{62}$ first crossed a transgenic line known as JPNL3, which expresses the P301L mutation associated with FTDP-17, with Tg2576 mice. Singly transgenic JPNL3 mice were known to develop NFT-like lesions, and bigenic mice [tau amyloid precursor protein (TAPP) mice] exhibited NFTs and amyloid plaques. More recently, Oddo et al ${ }^{63}$ generated a triply transgenic model ( $3 \times \mathrm{Tg}-\mathrm{AD}$ ) by coinjecting 2 transgenes containing APP-Swedish and P301L FTDP-17 mutations into fertilized eggs harvested from PS1M146V knock-in mice. The resulting transgenic lines thus expressed mutations in APP and tau from exogenous transgenes combined with a PS1 FAD mutation from the endogenous mouse gene. With aging, these mice had increased $\mathrm{A} \beta 40$ and $\mathrm{A} \beta 42$ levels. Intraneuronal $\mathrm{A} \beta$ accumulated, and the mice exhibited amyloid plaques and NFT-like lesions that immunostained with antibodies recognizing conformationally altered tau epitopes. Amyloid plaques were apparent by 6 months of age and preceded tau pathology, which was not evident until about 1 year of age. Functionally, $3 \mathrm{xTg}$-AD mice developed age-dependent synaptic dysfunction, including altered long-term potentiation and deficits in spatial memory. ${ }^{63}, 64$

TAPP and 3xTg-AD thus exhibit a broader spectrum of AD pathologies. The question, however, again arises: are these models of AD? They do exhibit the much sought after plaques with a tangle pathology. However, they represent a composite of 2 distinct diseases that do not naturally occur together. Plaque development is almost certainly driven by the APP and PS1 FAD mutations, whereas the tangle-like pathology is driven by the tau mutations. Indeed, in $3 \times \mathrm{Tg}-\mathrm{AD}$ mice, the pathologies arise in spatially distinct patterns, with 
$\mathrm{A} \beta$ deposition starting in the neocortex and appearing later in the hippocampus, whereas tau pathology progresses in the opposite direction, beginning in the hippocampus and appearing later in the neocortex ${ }^{63}$ It does, however, appear that the mutations interact because in TAPP mice, NFTs are found in regions that rarely or never exhibit NFTs in singly transgenic JPNL3 animals. In addition, intracerebral injections of anti-A $\beta$ antibodies into the hippocampus of $3 \mathrm{xTg}-\mathrm{AD}$ mice not only reduced $\mathrm{A} \beta$ accumulation but also resulted in clearance of early-stage tau pathology, although later-stage lesions were resistant. ${ }^{65}$ These studies thus show that modulating $\mathrm{A} \beta$ affects tau pathology and suggest that tau pathology may be downstream of $A \beta$ generation; this notion has also been supported by recent studies showing that behavioral deficits in APP FAD mutant mice are reduced when endogenous tau is removed by breeding the APP transgene onto a tau-null background. ${ }^{66}$

Finally, all the transgenic mouse models discussed are based on the expression of mutant genes implicated in causing $\mathrm{AD}$ in a relatively small subset of patients. Except for their generally early age of onset, these familial cases appear to phenocopy quite well the clinical and pathological features of sporadic cases, but it remains possible that the mutations themselves introduce effects that are not found in the sporadic disease. In particular, presenilins affect a range of biological functions through effects that are not dependent on their role in $\gamma$-secretase activity, and at least some of these activities are known to be altered by FAD mutants. ${ }^{23}$

\section{USE OF TRANSGENIC MODELS TO STUDY THE PATHOPHYSIOLOGY OF ALZHEIMER'S DISEASE: EFFECTS OF DIFFERENT $\beta$-AMYLOID SPECIES}

Transgenic mice have been used to study many aspects of AD pathophysiology. Two recent examples of their usefulness are studies designed to test differences in the in vivo effects of $\mathrm{A} \beta 40$ and $\mathrm{A} \beta 42$. In vitro, $\mathrm{A} \beta 42$ is more amyloidogenic than $\mathrm{A} \beta 40 .{ }^{67}$ However, $\mathrm{A} \beta 40$ is found in plaque amyloid and is especially common in vascular amyloid. ${ }^{68}$ In vitro studies have suggested, however, that $\mathrm{A} \beta 42$ deposition is necessary in order to seed $\mathrm{A} \beta 40$ containing deposits. ${ }^{69}$ To test the relative plaque-forming propensity in vivo, transgenic mice were generated that selectively express either $\mathrm{A} \beta 40$ or $\mathrm{A} \beta 42 .{ }^{70}$ These mice were created by the fusion of $\mathrm{A} \beta 40$ and $\mathrm{A} \beta 42$ coding sequences to the $\mathrm{C}$-terminus of the BRI protein associated with familial British dementia. BRI is a transmembrane protein that undergoes constitutive cleavage near its $\mathrm{C}$-terminus that releases a soluble 23-amino acid peptide. $\mathrm{A} \beta 40$ or $\mathrm{A} \beta 42$ selective expression systems were created by the replacement of the 23 -amino acid BRI peptide region with human $\mathrm{A} \beta 40$ or $\mathrm{A} \beta 42$ sequences. Thus, in the fusion construct, cleavage, rather than releasing the native BRI peptide, releases either human $\mathrm{A} \beta 40$ or $\mathrm{A} \beta 42$. Although highly artificial constructs, the Bri-A $\beta 40$ and Bri-A $\beta 42$ transgenes offer an elegantly simple system for introducing human $\mathrm{A} \beta 40$ or $\mathrm{A} \beta 42$ into the mouse brain. Insoluble $\mathrm{A} \beta 42$ accumulated with aging in BRI-A $\beta 42$ transgenic mice and was accompanied by amyloid deposition in the parenchyma in the form of both plaques and diffuse deposits as well as extensive vascular amyloid deposition. By contrast, BRI-A $\beta 40$ mice developed no amyloid pathology at any age. These studies are thus consistent with $\mathrm{A} \beta 42$ being required for parenchymal and vascular deposits of $\mathrm{A} \beta 40$, and indeed, more recent studies have shown that BRI mice expressing high levels of $\mathrm{A} \beta 40$ are protected against amyloid deposition when bred with BRI-A $\beta 42$ mice. ${ }^{71}$

Both parenchymal and vascular deposits of amyloid are typical of AD. There are, however, mutations in APP that do not produce substantial parenchymal deposition in the form of plaques but result in extensive vascular deposits. These mutations, rather than producing FAD, cause a hereditary form of recurrent intracerebral hemorrhage. One such mutation, E693Q, is known as the Dutch mutation. Interestingly, although most FAD mutations in 
APP reside near the $\beta$ - and $\gamma$-secretase cleavage sites, mutations associated with cerebral hemorrhage such as the Dutch mutation tend to be found within the $\mathrm{A} \beta$ domain itself.

Herzig et al. ${ }^{47}$ developed transgenic lines that expressed human wild-type APP, APP-Dutch, or APP-Dutch crossed with a PS1 FAD mutant. These lines exhibited various A $\beta 40 / A \beta 42$ ratios, with the APP-Dutch ratio higher than the wild-type APP ratio, which was in turn greater than the APP-Dutch/PS1 ratio. The high A $\beta 40 / \mathrm{A} \beta 42$ ratio in the APP-Dutch mice resulted in extensive vascular amyloid deposition with essentially no parenchymal deposition. By contrast, APP-Dutch/PS1 mice with about half the A $\beta 40 / \mathrm{A} \beta 42$ ratio of APPDutch mice developed parenchymal plaques with little vascular deposition, and wild-type APP mice with intermediate $A \beta 40 / A \beta 42$ ratios had mixed parenchymal and vascular deposition. Thus, although $\mathrm{A} \beta 42$ may be needed as a seed for amyloid deposition in either compartment, these studies suggest that $\mathrm{A} \beta 40$ promotes vascular deposition, whereas $\mathrm{A} \beta 42$ shifts deposition toward parenchymal amyloid. Other studies ${ }^{72}$ have, however, found that transgenic mice harboring a distinct 693 mutation (E693G/Arctic) combined with APPSwedish and APP-Indiana mutations develop prominent parenchymal plaque deposits with little congophilic angiopathy despite high $\mathrm{A} \beta 40 / \mathrm{A} \beta 42$ ratios. Thus, some property of mutations at the 693 site, besides their effect on $\mathrm{A} \beta 40 / \mathrm{A} \beta 42$ ratios, also appears to influence parenchymal deposition versus vascular deposition.

\section{TRANSGENIC MODELS AND THE RISE OF THE $\beta$-AMYLOID OLIGOMER}

The original amyloid hypothesis regarded $\mathrm{A} \beta$ deposited in plaque amyloid as the toxic species. However, subsequently it became clear that plaque counts correlate relatively poorly with the level of cognitive decline and that in fact the number of NFTs correlates more strongly with the degree of dementia. ${ }^{73}$ This led to a reevaluation of what form of amyloid might constitute the most toxic species, and recently, soluble forms of $\mathrm{A} \beta$ have been proposed as the more toxic species.

Soluble A $\beta$ species are toxic in cell culture. ${ }^{74}$ APP transgenic mice have provided strong circumstantial evidence for the toxicity of $\mathrm{A} \beta$ oligomers in vivo by showing that many pathological and functional changes in mice occur before the appearance of plaque pathology. For example, a series of studies in PDAPP mice demonstrated that volume loss and other anatomic changes in the dentate gyrus are present in 100-day-old mice well before plaque deposition. ${ }^{75},{ }^{76} \mathrm{Tg} 2576$ mice also exhibit electro-physiological and behavioral changes months before plaque deposition, ${ }^{77}$ and axonal swellings may be present in $\mathrm{Tg} 2576$ mice for up to a year before amyloid deposition. ${ }^{78}$ Behavioral and electrophysiological changes have been described in other lines of APP mice before amyloid deposition as well. ${ }^{30},{ }^{79},{ }^{80}$ The finding of pathophysiological changes in PS1 FAD mutant mice (discussed previously) that have elevated $\mathrm{A} \beta 42$ but no plaques is also consistent with a toxic role for soluble forms of $\mathrm{A} \beta$.

Recently, a $56-\mathrm{kDa}$ oligomeric $\mathrm{A} \beta$ species identified in $\mathrm{Tg} 2576$ mice ${ }^{81}$ has been proposed as a candidate for the toxic effect. Levels of this species, which has been termed $\mathrm{A} \beta^{*} 56$, correlate strongly with the degree of memory impairment in $\mathrm{Tg} 2576$ mice, and when injected into rats, $\mathrm{A} \beta * 56$ disrupts cognitive functioning. ${ }^{81}$ Studies in $3 \mathrm{xTg}-\mathrm{AD}$ suggest that levels of $\mathrm{A} \beta^{* 56}$ may correlate with pathology and behavioral changes in this line as well. ${ }^{82}$

\section{$\beta$-AMYLOID IMMUNIZATION AS A THERAPEUTIC STRATEGY IN ALZHEIMER'S DISEASE}

Transgenic animals have been widely used to study factors that affect $\mathrm{A} \beta$ deposition. For example, the role that apolipoprotein $\mathcal{E} 4$ and its isoforms play in the development of plaque 
pathology has been extensively studied with apolipoprotein $\varepsilon 4$ transgenic and knockout mice crossed to APP transgenic mice. ${ }^{83}{ }^{85}$ Studies examining how dietary cholesterol affects plaque pathology in transgenic mice ${ }^{86}$ have formed part of the basis for proposals to use statin therapy for AD. Indeed, APP transgenic mice have been used to evaluate a variety of factors that influence $\mathrm{A} \beta$ production and plaque pathology; these factors range from inflammatory modulators, metal chelators, and natural products that bind $\mathrm{A} \beta$ to lifestyle factors including exercise, environmental enrichment, caloric restriction, and wine consumption. ${ }^{10}, 87 \_90$

However, nowhere have transgenic mice played a larger role than in the development of potential immunotherapies for AD. The initial impetus for immunotherapeutic approaches in $\mathrm{AD}$ came from in vitro observations showing that anti-A $\beta$ antibodies could prevent fibril formation and disaggregate preformed fibrils. ${ }^{91}$ However, without studies in transgenic mice demonstrating potential effectiveness in vivo, it seems unlikely that these approaches would have ever made their way into human trials.

Schenk et al., ${ }^{92}$ using aggregated $\mathrm{A} \beta$ as an immunogen, first investigated $\mathrm{A} \beta$ vaccination in PDAPP mice. They started immunizing mice at 6 weeks of age (well before the age when plaque deposition begins in this line) with a vaccine that was injected on a monthly basis for 11 months. High titers of anti-A $\beta$ antibodies developed, and at 12 months of age, the mice showed dramatic reductions in plaque loads in comparison with saline-injected controls. In an additional set of studies, 11-month-old mice with already existing plaque loads received monthly injections and were examined pathologically at 15 and 18 months. At both ages, plaque burdens were dramatically less in the immunized animals, suggesting that $\mathrm{A} \beta$ vaccination might be beneficial even after parenchymal deposits are present.

Other groups soon confirmed the beneficial effects of active immunization in other transgenic lines and showed that vaccination can reverse spatial memory deficits in APP and presenilin/APP mice. ${ }^{93},{ }^{94}$ Strikingly, behavioral performance often improved more than brain $\mathrm{A} \beta$ levels or plaque pathology, with deficits in some lines being almost entirely normalized. ${ }^{17}$ Subsequently, it was found that passive immunization of anti-A $\beta$ antibodies peripherally also reduced amyloid deposition. ${ }^{95}, 96$ Indeed, multiple studies have shown that even short-term administration of anti-A $\beta$ antibodies improves performance in tests of learning and memory. ${ }^{97}$ Improvements in behavioral performance with passive immunization strategies also occur even when no detectible effect is seen on deposits of plaque amyloid. For example, Dodart et al. ${ }^{98}$ gave weekly injections of the anti-A $\beta$ monoclonal antibody m266 for 6 weeks to 24-month-old PDAPP mice and found that behavioral impairments were essentially normalized despite there being no effects on plaque pathology. Indeed, even a single injection of this antibody to 11-month-old mice produced beneficial effects on behavior that were apparent after 1 day of treatment. ${ }^{98}$ Similar effects have been observed with a different monoclonal antibody in Tg2576 mice. ${ }^{99}$

How immunization works remains uncertain. Multiple mechanisms have been suggested, including stimulation of antibody-induced phagocytosis of plaque deposits as well as induction of cell-mediated immune responses. Anti-A $\beta$ antibodies might also directly disrupt existing aggregates, impede the formation of new aggregates, or neutralize toxic soluble species of $\mathrm{A} \beta$. Peripheral administration of anti-A $\beta$ antibodies has also been shown to induce massive increases in plasma $\mathrm{A} \beta,{ }^{96},{ }^{100}$ suggesting that passive immunization may promote an efflux of $\mathrm{A} \beta$ out of the brain into what has been called a peripheral sink. These mechanisms as well as others have recently been reviewed. ${ }^{97},{ }^{101}$

Whatever its mechanism of action, studies in transgenic mice were sufficiently compelling that $\mathrm{A} \beta$ immunization was taken into clinical trials in humans. In the first of these studies, 
the AN1792 trial, subjects were injected with an aggregated $\mathrm{A} \beta$ preparation similar to that used in the initial mouse studies. Although phase 1 studies indicated adequate immunological responses and tolerability of the vaccine, phase 2 studies in patients with AD were halted because of the appearance of an autoimmune meningoencephalitis in some patients. ${ }^{102}$ Although these initial studies were ultimately disappointing, a retrospective analysis found that those patients with the highest anti-A $\beta$ titers had significantly less cognitive decline than those with low titers, ${ }^{103}$ arguing that active immunization remains a viable strategy if autoimmune side effects can be overcome. Most human trials are, however, currently pursuing passive immunization strategies because of the greater control over antibody levels that can be achieved as well as concerns over the ability of older subjects to mount an effective immune response. The farthest advanced of these trails at the time of writing is the Elan/Wyeth trial of AAB-001 (bapineuzumab), which entered phase III testing in 2007 and uses a humanized monoclonal antibody directed against the Nterminus of $\mathrm{A} \beta$. More information on this and other current clinical trials can be found at http://www.clinicaltrials.gov and http://alzforum.com.

\section{CONCLUSION}

Animal models attempt to mimic human diseases and thus allow testing of therapeutic strategies as well as the investigation of the disease course and underlying pathophysiology in a manner that is impractical or unethical in humans. Transgenic models now dominate approaches to animal modeling of human neurodegenerative diseases, including AD. In one sense, the models are limited by their requirement for a genetic modification. However, the discovery of genes for familial forms of AD has allowed transgenic models to be created that reproduce many critical aspects of the disease. These models have improved our understanding of the disease pathogenesis and have led to new therapeutic approaches. They will, without a doubt, continue to play central roles for years to come in preclinical testing and be used as tools for developing insight into the biological basis of AD.

\section{Acknowledgments}

Work conducted in the authors' laboratory has been supported by grants from the National Institute on Aging (AG20139, AG029361, AG02219, and AG05138), the Alzheimer's Association (IIRG-07-57 318) and a Merit Award from the Department of Veterans Affairs (1I01BX000342).

\section{References}

1. Link CD. Invertebrate models of Alzheimer's disease. Genes Brain Behav. 2005; 4:147-156. [PubMed: 15810903]

2. Wu Y, Luo Y. Transgenic C. elegans as a model in Alzheimer's research. Curr Alzheimer Res. 2005; 2:37-45. [PubMed: 15977988]

3. Folkesson R, Malkiewicz K, Kloskowska E, et al. A transgenic rat expressing human APP with the Swedish Alzheimer's disease mutation. Biochem Biophys Res Commun. 2007; 358:777-782. [PubMed: 17506994]

4. Agca C, Fritz JJ, Walker LC, et al. Development of transgenic rats producing human beta-amyloid precursor protein as a model for Alzheimer's disease: transgene and endogenous APP genes are regulated tissue-specifically. BMC Neurosci. 2008; 9:28. [PubMed: 18302776]

5. Flood DG, Lin YG, Lang DM, et al. A transgenic rat model of Alzheimer's disease with extracellular Abeta deposition. Neurobiol Aging. 2009; 30:1078-1090. [PubMed: 18053619]

6. Liu L, Orozco IJ, Planel E, et al. A transgenic rat that develops Alzheimer's disease-like amyloid pathology, deficits in synaptic plasticity and cognitive impairment. Neurobiol Dis. 2008; 31:46-57. [PubMed: 18504134]

7. Selkoe DJ. Alzheimer's disease: genes, proteins, and therapy. Physiol Rev. 2001; 81:741-766. [PubMed: 11274343] 
8. Ertekin-Taner N. Genetics of Alzheimer's disease: a centennial review. Neurol Clin. 2007; 25:611667. [PubMed: 17659183]

9. Codita A, Winblad B, Mohammed AH. Of mice and men: more neurobiology in dementia. Curr Opin Psychiatry. 2006; 19:555-563. [PubMed: 17012931]

10. Games D, Buttini M, Kobayashi D, et al. Mice as models: transgenic approaches and Alzheimer's disease. J Alzheimers Dis. 2006; 9(suppl):133-149. [PubMed: 16914852]

11. McGowan E, Eriksen J, Hutton M. A decade of modeling Alzheimer's disease in transgenic mice. Trends Genet. 2006; 22:281-289. [PubMed: 16567017]

12. Games D, Adams D, Alessandrini R, et al. Alzheimer-type neuropathology in transgenic mice overexpressing V717F beta-amyloid precursor protein. Nature. 1995; 373:523-527. [PubMed: 7845465]

13. Reilly JF, Games D, Rydel RE, et al. Amyloid deposition in the hippocampus and entorhinal cortex: quantitative analysis of a transgenic mouse model. Proc Natl Acad Sci U S A. 2003; 100:4837-4842. [PubMed: 12697936]

14. Chen G, Chen KS, Knox J, et al. A learning deficit related to age and beta-amyloid plaques in a mouse model of Alzheimer's disease. Nature. 2000; 408:975-979. [PubMed: 11140684]

15. Dodart JC, Mathis C, Saura J, et al. Neuroanatomical abnormalities in behaviorally characterized APP(V717F) transgenic mice. Neurobiol Dis. 2000; 7:71-85. [PubMed: 10783292]

16. Hsiao K, Chapman P, Nilsen S, et al. Correlative memory deficits, Abeta elevation, and amyloid plaques in transgenic mice. Science. 1996; 274:99-102. [PubMed: 8810256]

17. Chishti MA, Yang DS, Janus C, et al. Early-onset amyloid deposition and cognitive deficits in transgenic mice expressing a double mutant form of amyloid precursor protein 695. J Biol Chem. 2001; 276:21562-21570. [PubMed: 11279122]

18. Calhoun ME, Burgermeister P, Phinney AL, et al. Neuronal overexpression of mutant amyloid precursor protein results in prominent deposition of cerebrovascular amyloid. Proc Natl Acad Sci U S A. 1999; 96:14088-14093. [PubMed: 10570203]

19. Fryer JD, Taylor JW, DeMattos RB, et al. Apolipoprotein E markedly facilitates age-dependent cerebral amyloid angiopathy and spontaneous hemorrhage in amyloid precursor protein transgenic mice. J Neurosci. 2003; 23:7889-7896. [PubMed: 12944519]

20. Sasaki A, Shoji M, Harigaya Y, et al. Amyloid cored plaques in $\mathrm{Tg} 2576$ transgenic mice are characterized by giant plaques, slightly activated microglia, and the lack of paired helical filamenttyped, dystrophic neurites. Virchows Arch. 2002; 441:358-367. [PubMed: 12404061]

21. Hsiao KK, Borchelt DR, Olson K, et al. Age-related CNS disorder and early death in transgenic FVB/N mice overexpressing Alzheimer amyloid precursor proteins. Neuron. 1995; 15:1203-1218. [PubMed: 7576662]

22. Zheng H, Koo EH. The amyloid precursor protein: beyond amyloid. Mol Neurodegener. 2006; 1:5. [PubMed: 16930452]

23. Vetrivel KS, Zhang YW, Xu H, Thinakaran G. Pathological and physiological functions of presenilins. Mol Neurodegener. 2006; 1:4. [PubMed: 16930451]

24. Duff K, Eckman C, Zehr C, et al. Increased amyloid-beta42(43) in brains of mice expressing mutant presenilin 1. Nature. 1996; 383:710-713. [PubMed: 8878479]

25. Borchelt DR, Thinakaran G, Eckman CB, et al. Familial Alzheimer's disease-linked presenilin 1 variants elevate Abeta1-42/1-40 ratio in vitro and in vivo. Neuron. 1996; 17:1005-1013. [PubMed: 8938131]

26. Citron M, Westaway D, Xia W, et al. Mutant presenilins of Alzheimer's disease increase production of 42-residue amyloid beta-protein in both transfected cells and transgenic mice. Nat Med. 1997; 3:67-72. [PubMed: 8986743]

27. Guo Q, Sebastian L, Sopher BL, et al. Increased vulnerability of hippocampal neurons from presenilin-1 mutant knock-in mice to amyloid beta-peptide toxicity: central roles of superoxide production and caspase activation. J Neurochem. 1999; 72:1019-1029. [PubMed: 10037473]

28. Flood DG, Reaume AG, Dorfman KS, et al. FAD mutant PS-1 gene-targeted mice: increased A beta 42 and A beta deposition without APP overproduction. Neurobiol Aging. 2002; 23:335-348. [PubMed: 11959395] 
29. Nakano Y, Kondoh G, Kudo T, et al. Accumulation of murine amyloidbeta42 in a gene-dosagedependent manner in PS1 'knock-in' mice. Eur J Neurosci. 1999; 11:2577-2581. [PubMed: 10383647]

30. Holcomb L, Gordon MN, McGowan E, et al. Accelerated Alzheimer-type phenotype in transgenic mice carrying both mutant amyloid precursor protein and presenilin 1 transgenes. Nat Med. 1998; 4:97-100. [PubMed: 9427614]

31. Jankowsky JL, Younkin LH, Gonzales V, et al. Rodent A beta modulates the solubility and distribution of amyloid deposits in transgenic mice. J Biol Chem. 2007; 282:22707-22720. [PubMed: 17556372]

32. Grilli M, Diodato E, Lozza G, et al. Presenilin-1 regulates the neuronal threshold to excitotoxicity both physiologically and pathologically. Proc Natl Acad Sci U S A. 2000; 97:12822-12827. [PubMed: 11070093]

33. Schneider I, Reverse D, Dewachter I, et al. Mutant presenilins disturb neuronal calcium homeostasis in the brain of transgenic mice, decreasing the threshold for excitotoxicity and facilitating long-term potentiation. J Biol Chem. 2001; 276:11539-11544. [PubMed: 11278803]

34. Kassed CA, Butler TL, Navidomskis MT, et al. Mice expressing human mutant presenilin-1 exhibit decreased activation of NF-kappaB p50 in hippocampal neurons after injury. Mol Brain Res. 2003; 110:152-157. [PubMed: 12573544]

35. Lazarov O, Peterson LD, Peterson DA, Sisodia SS. Expression of a familial Alzheimer's diseaselinked presenilin-1 variant enhances perforant pathway lesion-induced neuronal loss in the entorhinal cortex. J Neurosci. 2006; 26:429-434. [PubMed: 16407539]

36. Mohmmad Abdul H, Wenk GL, Gramling M, et al. APP and PS-1 mutations induce brain oxidative stress independent of dietary cholesterol: implications for Alzheimer's disease. Neurosci Lett. 2004; 368:148-150. [PubMed: 15351438]

37. Schuessel K, Frey C, Jourdan C, et al. Aging sensitizes toward ROS formation and lipid peroxidation in PS1M146L transgenic mice. Free Radic Biol Med. 2006; 40:850-862. [PubMed: 16520237]

38. Chevallier NL, Soriano S, Kang DE, et al. Perturbed neurogenesis in the adult hippocampus associated with presenilin-1 A246E mutation. Am J Pathol. 2005; 167:151-159. [PubMed: 15972961]

39. Choi SH, Veeraraghavalu K, Lazarov O, et al. Non-cell-autonomous effects of presenilin 1 variants on enrichment-mediated hippocampal progenitor cell proliferation and differentiation. Neuron. 2008; 59:568-580. [PubMed: 18760694]

40. Wang R, Dineley KT, Sweatt JD, Zheng H. Presenilin 1 familial Alzheimer's disease mutation leads to defective associative learning and impaired adult neurogenesis. Neuroscience. 2004; 126:305-312. [PubMed: 15207348]

41. Wen PH, Shao X, Shao Z, et al. Overexpression of wild type but not an FAD mutant presenilin-1 promotes neurogenesis in the hippocampus of adult mice. Neurobiol Dis. 2002; 10:8-19. [PubMed: 12079399]

42. Wen PH, Hof PR, Chen X, et al. The presenilin-1 familial Alzheimer disease mutant P117L impairs neurogenesis in the hippocampus of adult mice. Exp Neurol. 2004; 188:224-237. [PubMed: 15246822]

43. Auffret A, Gautheron V, Repici M, et al. Age-dependent impairment of spine morphology and synaptic plasticity in hippocampal CA1 neurons of a presenilin 1 transgenic mouse model of Alzheimer's disease. J Neurosci. 2009; 29:10144-10152. [PubMed: 19675248]

44. Chui DH, Tanahashi H, Ozawa K, et al. Transgenic mice with Alzheimer presenilin 1 mutations show accelerated neurodegeneration without amyloid plaque formation. Nat Med. 1999; 5:560564. [PubMed: 10229234]

45. Tanemura K, Chui DH, Fukuda T, et al. Formation of tau inclusions in knock-in mice with familial Alzheimer disease (FAD) mutation of presenilin 1 (PS1). J Biol Chem. 2006; 281:5037-5041. [PubMed: 16377636]

46. Gama Sosa M, De Gasperi R, Rocher A, et al. Age-related vascular pathology in transgenic mice expressing presenilin 1-associated familial Alzheimer's disease mutations. Am J Pathol. 10.2353/ ajpath.2010.090482 
47. Herzig MC, Winkler DT, Burgermeister P, et al. Abeta is targeted to the vasculature in a mouse model of hereditary cerebral hemorrhage with amyloidosis. Nat Neurosci. 2004; 7:954-960. [PubMed: 15311281]

48. Reaume AG, Howland DS, Trusko SP, et al. Enhanced amyloidogenic processing of the betaamyloid precursor protein in gene-targeted mice bearing the Swedish familial Alzheimer's disease mutations and a "humanized" Abeta sequence. J Biol Chem. 1996; 271:23380-23388. [PubMed: 8798542]

49. Zigman WB, Schupf N, Sersen E, Silverman W. Prevalence of dementia in adults with and without Down syndrome. Am J Ment Retard. 1996; 100:403-412. [PubMed: 8718994]

50. Kasuga K, Shimohata T, Nishimura A, et al. Identification of independent APP locus duplication in Japanese patients with early-onset Alzheimer disease. J Neurol Neurosurg Psychiatry. 2009; 80:1050-1052. 51. [PubMed: 19684239]

51. Sleegers K, Brouwers N, Gijselinck I, et al. APP duplication is sufficient to cause early onset Alzheimer's dementia with cerebral amyloid angiopathy. Brain. 2006; 129:2977-2983. [PubMed: 16921174]

52. Price JL, Morris JC. Tangles and plaques in nondemented aging and "preclinical" Alzheimer's disease. Ann Neurol. 1999; 45:358-368. [PubMed: 10072051]

53. Irizarry MC, McNamara M, Fedorchak K, et al. APPSw transgenic mice develop age-related A beta deposits and neuropil abnormalities, but no neuronal loss in CA1. J Neuropathol Exp Neurol. 1997; 56:965-973. [PubMed: 9291938]

54. Irizarry MC, Soriano F, McNamara M, et al. Abeta deposition is associated with neuropil changes, but not with overt neuronal loss in the human amyloid precursor protein V717F (PDAPP) transgenic mouse. J Neurosci. 1997; 17:7053-7059. [PubMed: 9278541]

55. Calhoun ME, Wiederhold KH, Abramowski D, et al. Neuron loss in APP transgenic mice. Nature. 1998; 395:755-756. [PubMed: 9796810]

56. Casas C, Sergeant N, Itier JM, et al. Massive CA1/2 neuronal loss with intraneuronal and Nterminal truncated Abeta42 accumulation in a novel Alzheimer transgenic model. Am J Pathol. 2004; 165:1289-1300. [PubMed: 15466394]

57. Schmitz C, Rutten BP, Pielen A, et al. Hippocampal neuron loss exceeds amyloid plaque load in a transgenic mouse model of Alzheimer's disease. Am J Pathol. 2004; 164:1495-1502. [PubMed: 15039236]

58. Oakley H, Cole SL, Logan S, et al. Intraneuronal beta-amyloid aggregates, neurodegeneration, and neuron loss in transgenic mice with five familial Alzheimer's disease mutations: potential factors in amyloid plaque formation. J Neurosci. 2006; 26:10129-10140. [PubMed: 17021169]

59. Duyckaerts C, Potier MC, Delatour B. Alzheimer disease models and human neuropathology: similarities and differences. Acta Neuropathol. 2008; 115:5-38. [PubMed: 18038275]

60. Masliah E, Sisk A, Mallory M, Games D. Neurofibrillary pathology in transgenic mice overexpressing V717F beta-amyloid precursor protein. J Neuropathol Exp Neurol. 2001; 60:357368. [PubMed: 11305871]

61. Haugarvoll K, Wszolek ZK, Hutton M. The genetics of frontotemporal dementia. Neurol Clin. 2007; 25:697-715. [PubMed: 17659186]

62. Lewis J, Dickson DW, Lin WL, et al. Enhanced neurofibrillary degeneration in transgenic mice expressing mutant tau and APP. Science. 2001; 293:1487-1491. [PubMed: 11520987]

63. Oddo S, Caccamo A, Shepherd JD, et al. Triple-transgenic model of Alzheimer's disease with plaques and tangles: intracellular Abeta and synaptic dysfunction. Neuron. 2003; 39:409-421. [PubMed: 12895417]

64. Billings LM, Oddo S, Green KN, et al. Intraneuronal Abeta causes the onset of early Alzheimer's disease-related cognitive deficits in transgenic mice. Neuron. 2005; 45:675-688. [PubMed: 15748844]

65. Oddo S, Billings L, Kesslak JP, et al. Abeta immunotherapy leads to clearance of early, but not late, hyperphosphorylated tau aggregates via the proteasome. Neuron. 2004; 43:321-332. [PubMed: 15294141] 
66. Roberson ED, Scearce-Levie K, Palop JJ, et al. Reducing endogenous tau ameliorates amyloid beta-induced deficits in an Alzheimer's disease mouse model. Science. 2007; 316:750-754. [PubMed: 17478722]

67. Barrow CJ, Yasuda A, Kenny PT, Zagorski MG. Solution conformations and aggregational properties of synthetic amyloid beta-peptides of Alzheimer's disease. Analysis of circular dichroism spectra. J Mol Biol. 1992; 225:1075-1093. [PubMed: 1613791]

68. Kumar-Singh S. Cerebral amyloid angiopathy: pathogenetic mechanisms and link to dense amyloid plaques. Genes Brain Behav. 2008; 7(suppl 1):67-82. [PubMed: 18184371]

69. Fryer JD, Holtzman DM. The bad seed in Alzheimer's disease. Neuron. 2005; 47:167-168. [PubMed: 16039556]

70. McGowan E, Pickford F, Kim J, et al. Abeta42 is essential for parenchymal and vascular amyloid deposition in mice. Neuron. 2005; 47:191-199. [PubMed: 16039562]

71. Kim J, Onstead L, Randle S, et al. Abeta40 inhibits amyloid deposition in vivo. J Neurosci. 2007; 27:627-633. [PubMed: 17234594]

72. Cheng IH, Palop JJ, Esposito LA, et al. Aggressive amyloidosis in mice expressing human amyloid peptides with the Arctic mutation. Nat Med. 2004; 10:1190-1192. [PubMed: 15502844]

73. Arriagada PV, Growdon JH, Hedley-Whyte ET, Hyman BT. Neurofibrillary tangles but not senile plaques parallel duration and severity of Alzheimer's disease. Neurology. 1992; 42(pt 1):631-639. [PubMed: 1549228]

74. Walsh DM, Selkoe DJ. A beta oligomers-a decade of discovery. J Neurochem. 2007; 101:11721184. [PubMed: 17286590]

75. Redwine JM, Kosofsky B, Jacobs RE, et al. Dentate gyrus volume is reduced before onset of plaque formation in PDAPP mice: a magnetic resonance microscopy and stereologic analysis. Proc Natl Acad Sci U S A. 2003; 100:1381-1386. [PubMed: 12552120]

76. Wu CC, Chawla F, Games D, et al. Selective vulnerability of dentate granule cells prior to amyloid deposition in PDAPP mice: digital morphometric analyses. Proc Natl Acad Sci U S A. 2004; 101:7141-7146. [PubMed: 15118092]

77. Jacobsen JS, Wu CC, Redwine JM, et al. Early-onset behavioral and synaptic deficits in a mouse model of Alzheimer's disease. Proc Natl Acad Sci U S A. 2006; 103:5161-5166. [PubMed: 16549764]

78. Stokin GB, Lillo C, Falzone TL, et al. Axonopathy and transport deficits early in the pathogenesis of Alzheimer's disease. Science. 2005; 307:1282-1288. [PubMed: 15731448]

79. Hsia AY, Masliah E, McConlogue L, et al. Plaque-independent disruption of neural circuits in Alzheimer's disease mouse models. Proc Natl Acad Sci U S A. 1999; 96:3228-3233. [PubMed: 10077666]

80. Moechars D, Dewachter I, Lorent K, et al. Early phenotypic changes in transgenic mice that overexpress different mutants of amyloid precursor protein in brain. J Biol Chem. 1999; 274:6483-6492. [PubMed: 10037741]

81. Lesne S, Koh MT, Kotilinek L, et al. A specific amyloid-beta protein assembly in the brain impairs memory. Nature. 2006; 440:352-357. [PubMed: 16541076]

82. Billings LM, Green KN, McGaugh JL, LaFerla FM. Learning decreases A beta*56 and tau pathology and ameliorates behavioral decline in 3xTg-AD mice. J Neurosci. 2007; 27:751-761. [PubMed: 17251414]

83. Bales KR, Verina T, Dodel RC, et al. Lack of apolipoprotein E dramatically reduces amyloid betapeptide deposition. Nat Genet. 1997; 17:263-264. [PubMed: 9354781]

84. Holtzman DM, Bales KR, Tenkova T, et al. Apolipoprotein E isoform-dependent amyloid deposition and neuritic degeneration in a mouse model of Alzheimer's disease. Proc Natl Acad Sci U S A. 2000; 97:2892-2897. [PubMed: 10694577]

85. Fagan AM, Watson M, Parsadanian M, et al. Human and murine ApoE markedly alters A beta metabolism before and after plaque formation in a mouse model of Alzheimer's disease. Neurobiol Dis. 2002; 9:305-318. [PubMed: 11950276]

86. Refolo LM, Pappolla MA, LaFrancois J, et al. A cholesterol-lowering drug reduces beta-amyloid pathology in a transgenic mouse model of Alzheimer's disease. Neurobiol Dis. 2001; 8:890-899. [PubMed: 11592856] 
87. Wang J, Ho L, Zhao Z, et al. Moderate consumption of cabernet sauvignon attenuates Abeta neuropathology in a mouse model of Alzheimer's disease. FASEB J. 2006; 20:2313-2320. [PubMed: 17077308]

88. Adlard PA, Perreau VM, Pop V, Cotman CW. Voluntary exercise decreases amyloid load in a transgenic model of Alzheimer's disease. J Neurosci. 2005; 25:4217-4221. [PubMed: 15858047]

89. Patel NV, Gordon MN, Connor KE, et al. Caloric restriction attenuates Abeta-deposition in Alzheimer transgenic models. Neurobiol Aging. 2005; 26:995-1000. [PubMed: 15748777]

90. Lazarov O, Robinson J, Tang YP, et al. Environmental enrichment reduces Abeta levels and amyloid deposition in transgenic mice. Cell. 2005; 120:701-713. [PubMed: 15766532]

91. Solomon B, Koppel R, Hanan E, Katzav T. Monoclonal antibodies inhibit in vitro fibrillar aggregation of the Alzheimer beta-amyloid peptide. Proc Natl Acad Sci U S A. 1996; 93:452-455. [PubMed: 8552659]

92. Schenk D, Barbour R, Dunn W, et al. Immunization with amyloid-beta attenuates Alzheimerdisease-like pathology in the PDAPP mouse. Nature. 1999; 400:173-177. [PubMed: 10408445]

93. Janus C, Pearson J, McLaurin J, et al. A beta peptide immunization reduces behavioural impairment and plaques in a model of Alzheimer's disease. Nature. 2000; 408:979-982. [PubMed: 11140685]

94. Morgan D. Immunotherapy for Alzheimer's disease. J Alzheimers Dis. 2006; 9(suppl):425-432. [PubMed: 16914881]

95. Bard F, Cannon C, Barbour R, et al. Peripherally administered antibodies against amyloid betapeptide enter the central nervous system and reduce pathology in a mouse model of Alzheimer disease. Nat Med. 2000; 6:916-919. [PubMed: 10932230]

96. DeMattos RB, Bales KR, Cummins DJ, et al. Peripheral anti-A beta antibody alters CNS and plasma A beta clearance and decreases brain A beta burden in a mouse model of Alzheimer's disease. Proc Natl Acad Sci U S A. 2001; 98:8850-8855. [PubMed: 11438712]

97. Brody DL, Holtzman DM. Active and passive immunotherapy for neurodegenerative disorders. Annu Rev Neurosci. 2008; 31:175-193. [PubMed: 18352830]

98. Dodart JC, Bales KR, Gannon KS, et al. Immunization reverses memory deficits without reducing brain Abeta burden in Alzheimer's disease model. Nat Neurosci. 2002; 5:452-457. [PubMed: 11941374]

99. Kotilinek LA, Bacskai B, Westerman M, et al. Reversible memory loss in a mouse transgenic model of Alzheimer's disease. J Neurosci. 2002; 22:6331-6335. [PubMed: 12151510]

100. DeMattos RB, Bales KR, Cummins DJ, et al. Brain to plasma amyloid-beta efflux: a measure of brain amyloid burden in a mouse model of Alzheimer's disease. Science. 2002; 295:2264-2267. [PubMed: 11910111]

101. Wisniewski T, Konietzko U. Amyloid-beta immunisation for Alzheimer's disease. Lancet Neurol. 2008; 7:805-811. [PubMed: 18667360]

102. Orgogozo JM, Gilman S, Dartigues JF, et al. Subacute meningoencephalitis in a subset of patients with AD after Abeta42 immunization. Neurology. 2003; 61:46-54. [PubMed: 12847155]

103. Hock C, Konietzko U, Streffer JR, et al. Antibodies against beta-amyloid slow cognitive decline in Alzheimer's disease. Neuron. 2003; 38:547-554. [PubMed: 12765607] 
Table 1

Selected Examples of AD Mouse Models.

\begin{tabular}{|c|c|c|c|c|}
\hline Line & Promoter & FAD Mutation & Amyloid Pathology & Reference \\
\hline PDAPP & PDGF & APP-Indiana & Parenchymal plaques at 6-9 months of age & 12 \\
\hline $\operatorname{Tg} 2576$ & $\operatorname{PrP}$ & APP-Swedish & $\begin{array}{l}\text { Parenchymal plaques by } 11-13 \text { months of } \\
\text { age with some vascular amyloid }\end{array}$ & 16 \\
\hline APP23 & Thy-1 & APP-Swedish & $\begin{array}{l}\text { Parenchymal plaques by } 6 \text { months of age } \\
\text { and prominent vascular deposition of } \\
\text { amyloid }\end{array}$ & 18 \\
\hline TgCRND8 & $\operatorname{PrP}$ & APP-Swedish + Indiana & $\begin{array}{l}\text { More aggressive parenchymal plaque } \\
\text { pathology present by } 3 \text { months of age }\end{array}$ & 17 \\
\hline APP-Dutch & Thy-1 & $\begin{array}{l}\text { APPE693Q associated with } \\
\text { hereditary cerebral hemorrhage with } \\
\text { Dutch-type amyloidosis }\end{array}$ & $\begin{array}{l}\text { Vascular deposition of amyloid with few } \\
\text { parenchymal plaques }\end{array}$ & 47 \\
\hline PS1M146V & PDGF & PS1M146V & Elevated $\mathrm{A} \beta 42$ without plaque pathology & 24 \\
\hline PSAPP & $\mathrm{PS} 1 \mathrm{M} 146 \mathrm{~V} \times \mathrm{Tg} 2576$ & PS1M146V + APP-Swedish & $\begin{array}{l}\text { Earlier and more extensive plaque pathology } \\
\text { in comparison with } \mathrm{Tg} 2576 \text { alone }\end{array}$ & 30 \\
\hline $3 \times \mathrm{Tg}$ & $\begin{array}{l}\text { Thy- } 1.2 \text { and native } \\
\text { mouse }\end{array}$ & $\begin{array}{l}\text { Transgenes containing Thy-1.2- } \\
\text { driven APP-Swedish and tau P301L } \\
\text { were coinjected onto a homozygous } \\
\text { PS1M146V knock-in background. }\end{array}$ & $\begin{array}{l}\text { Parenchymal plaques by } 6 \text { months of age } \\
\text { combined with tau pathology by } 12 \text { months } \\
\text { of age }\end{array}$ & 63 \\
\hline
\end{tabular}

NOTE: Additional information on AD Tg models can be found at the Web site of the Alzheimer's Association (http://www.alzforum.org/res/com/ tra).

Abbreviations: $\mathrm{A} \beta, \beta$-amyloid; $\mathrm{AD}$, Alzheimer's disease; $\mathrm{APP}$, amyloid precursor protein; FAD, familial Alzheimer's disease; PDAPP, plateletderived growth factor promoter driving amyloid precursor protein; PDGF, platelet-derived growth factor $\beta$; PrP, prion protein; PS1, presenilin 1; PSAPP, presenilin/amyloid precursor protein; Tg, transgenic. 